they seem to have been careful about the syntax of the first thirty pages.

It is a pity that the Polish statistical literature, rich as it is in excellent publications, should now be represented by a book which was obsolescent when the original appeared twelve years ago. However, a practical statistician can still find in it a great deal of shrewd advice on gathering and presenting statistical data, and even curious examples of deliberately misleading graphs. The wealth of examples is certainly instructive in many ways, and notes on the early history of statistics, going as far back as Biblical times, are very interesting. A few statistical tables are always welcome. The book is well produced.

S. K. ZAREMBA

\section{ESSAYS OF TEILHARD DE CHARDIN}

\section{The Appearance of Man}

By Pierre Teilhard de Chardin. Translated by J. M. Cohen. Pp. 286. (London: William Collins, Sons and Co., Ltd., 1965.) 25s. net.

T HE Jesuit Teilhard de Chardin was a really great man. He was born in Central France, the son of what in England would have been called a 'gentleman farmer'. In his maturity, he was in the front rank as a palaeontologist, he was a first-rate geologist, a philosopher of note, and a profound Christian. Attention has to be paid to the opinions of such an individual. His books are widely read and have been translated into English. Indeed, at the moment, quite a cult of Teilhard de Chardin has grown up.

In spite of the foregoing facts, what, one is driven to ask, is the object of publishing or republishing old essays, some of which date back to 1913 and 1921 ? The subjects which Teilhard professed are rapidly expanding and changing as new information comes to hand. In 1921 Boule's book was the last word on the subject of fossil man and Teilhard's opinion of it was at that time well worth knowing; but nowadays much has changed-. including, naturally, Teilhard's own attitude to many problems. Indeed, the later essays in The Appearance of Man show this to have been the case. Of course, where he is writing of factual finds, of excavations in which he took part, the articles are dateless and invaluable. Such is the case for the two essays on Pekin Man. Again the illustrations in the essay entitled "The Question of Fossil Man" are particularly well chosen and useful: if one were asked to produce an illustration of Baron Blanc's Mousterian find of the Monte Circeo skull one would be hard put to it to recall where this was published, but it appears in this essay. Naturally the later artieles are of much more contemporary interest, especially those written after de Chardin's visit to South Africa towards the end of his life.

As an old friend of Teilhard I am glad to possess this book because, as well as being pregnant with new idoas, it also shows the evolution of the author's own thought. and perhaps it is in some sense as a historical document that it has been published. But anyone reading it for instructional purposes should note carefully the date when any particular essay was written. Thero is a preface by Desmond Collins which indeed briefly attempts to bring the reader up to date, and this, of course, is very helpful. Nevertheless this volume should not be classed with such works as The Phenomenon of Man, Le Milieu Divin, or The Future of Man. It is obviously not fair to compare a collection of purely scientific essays with those great works of philosophic thought, but I can only feel that Teilhard himself would have gently but gravely protested agrinst the republication of some of his writings which he would have been the first to describe as vieux jeux.

M. C. BurkitT

\section{JOHN HUNTER'S MUSEUM}

History of the Trustees of the Hunterian Collection By Sir Victor Negus. Pp. viii $+132+7$ plates. (Edinburgh and London: E. and S. Livingstone, Ltd., 1966.) 30s. net.

A $\mathrm{N}$ inestimable debt of gratitude is owed to two medical A men who have enriched knowledge by their collections, now held by trustees for the nation. One was the physician, Sir Hans Sloane, founder of the British Museum, the other the surgeon, John Hunter, whose memory is perpetuated by the Hunterian Collection.

Hunter in his Will desired that his museum should be kept intact and if no other purchaser appeared that it should be offered to the Government. He died in 1793. Soon afterwards England was at war with France. Dr. Matthew Baillie, Hunter's nephew, and Fverard Home. his brother-in-law, approached the Prime Minister, William Pitt, who said: "What! Buy bottles? We have not enough money to buy gunpowder".

Novertheless, in 1796, a committee was appointed to report; they advised purchase of the collection. Three years elapsed, and then in 1799 the Company of Surgeons, reconstituted by Royal Charter, received a parliamentary grant of $£ 15,000$ for the purchase and undertook to maintain the museum. Further grants were given later. In 1800 the Company became the Royal College of Surgeons of London. Trustees, pre-eminent in science and public life, were appointed and William Clift, Hunter's devoted assistant, was appointed curator. The Government also made certain terms and conditions of the Trust including a course of lectures on comparative anatomy. By 1818 the museum found a permanent home in the Royal College of Surgeons in Lincoln's Inn Fields.

The original collection comprised some 13,682 specimens. The physiological section was in two divisions; the first illustrated the structure and parts of a plant, animal or: man, and the second concerned the reproduction of the living individual, thereby continuing its species. Another division included pathological specimens and illustrated the effects of disease or injury on normal structures. Other, smaller sections contained specimens of human and comparative osteology, geology, monsters and malformations, undissected animals, vertebrates and invertebrates and stuffed animals and birds.

History of the Trustees of the Hunterian Collection recounts the later history of the Trustees and the museum. Sir Victor Negus gives concise notes of the eminent. scientists who have cared for and increased the value of the collection; for example, Sir Richard Owen, Sir William Flower, Sir Arthur Keith and Dr. Wood Jones, the first: Sir William Collins professor of anatomy and conservator of the Anatomy Museum.

During the First World War, storage in a sub-basement sufficed for protection of the collection. In the Second World War, although extra precautions including strengthening of the sub-basement were adopted in 1940, they proved inadequate in view of the increasingly destructive power of high explosives. On the night of May 10-11, 1941, a high-explosive bomb destroyed two-fifths of the original Hunterian specimens and three-fifths of the 60,000 specimens including the valuable collection made in the First World War. By careful salvage, about 26,000 out of 60,827 specimens were saved. The president of the College, Sir Hugh Lett, and the acting chairman of the Museum Committee, Sir Gordon Gordon-Taylor, procured accommodation for the salvaged collection at various institutions and private centres in the country.

At the conclusion of the War the collection was gradually brought back to Lincoln's Inn Fields. The specimens, with further additions, have now been arranged by Miss Jessie Dobson, the anatomy curator, in the rebuilt portion of the College. Generous contributions have been made by the Wolfson Trustees, by the MacRae Webb-Johnson Fund and by Fellows of the College. 